\title{
Feed synbiotic additive to improve the productivity and quality of rabbit meat
}

\author{
Elena Kurchaeva*, Aleksander Vostroilov, Elena Vysotskaya, and Igor Maksimov \\ Voronezh state agrarian University named after Emperor Peter the Great, 394087 Voronezh, Russia
}

\begin{abstract}
The study is dedicated to research into efficiency of influence of probiotic additive "Prostor" on productivity, chemical composition of meat of rabbits. The influence of synbiotic preparation "Prostor" on the population of male rabbits of hybrid form "Hypharm" of French breeding, selected at the age of 45 days. The study took place at the industrial complex of LLC "Lipetsk rabbit" in Khlevensky district of Lipetsk region. The animals were divided into control and experimental groups by the method of pairs-analogues. The control group of rabbits received the basic diet consisting of lall-mash feed PZK-92, while the rabbits of the experimental group received compound feed PZK-92-60-18, which included synbiotic "Prostor" in a dosage of $1 \mathrm{~g} / \mathrm{kg}$ of feed. Meat quality assessment was carried out at the age of 105 days after control slaughter in the amount of 3 animals from each group. The use of the stated dosage of synbiotic preparation had a positive effect on the productive indicators of rabbits (live weight, average daily growth). The morphological composition data showed that rabbits of the experimental group outperformed rabbits of the control group by $23.84 \%$ in terms of muscle mass. Analysis of the chemical composition of muscle tissue showed that the use of feed additives "ProStor" in a dosage of $1.0 \mathrm{~g}$ per $\mathrm{kg}$ of feed has a positive effect on meat productivity and quality of rabbit meat, which opens up prospects for the use of the preparation in the rabbit industry.
\end{abstract}

\section{Introduction}

In the livestock industry in recent years, due to the active economic activity, there is an increase in physical and chemical factors that negatively affect the physiological processes occurring in the body of animals. In this connection, there is a need to develop scientific approaches and recommendations on the technology of feeding farm animals, including young rabbits using ecologically safe additives that provide high-quality and safe raw materials.

It should be noted that rabbit breeding is one of the branches of animal husbandry, which is engaged in breeding the most precocious resources that can produce meat at a relatively low cost of feed and maintenance [13].

Intensive raising technologies introduced in the rabbit breeding industry allow increasing the number of raised animals, but lead to increased anthropogenic and microbiological load on the organism of breeding objects and causes primarily a violation of the processes of digestion and metabolism, a decrease in productivity, which are accompanied by various intestinal infections [4-6].

The provision of the population of the Voronezh region with meat of its own production is about $70 \%$. The main share of meat resources falls on beef and pork, as well as poultry. Rabbit meat production is only $2.5 \%$ of the total meat resources, which determines the need to expand this raw material segment and find ways to increase the productivity of precocious breeding facilities. In this regard, the region is working to find ways to increase the productivity of the farmed livestock.

Special attention in the cultivation of young rabbits is given to feeding technology using scientifically-based nutrition standards with the use of biologically active substances that ensure the usefulness of diets. In this regard, it is necessary to qualitatively change the nature of the food supply through the use of effective drugs of a new generation that have the ability to optimize metabolic processes of the body [7-11], which in their turn contributes to the preservation of livestock due to the normalization of microbial balance in the digestive tract, growth stimulation, increase in liveslok.

One of the important biological risks on rabbit farms is the high sensitivity of livestock to pathogenic microflora. To reduce the susceptibility of livestock to pathogenic infections, antimicrobial growth stimulants - antibiotics are used as feed additives, the mechanism of action of which is to reduce the number of microorganisms competing with rabbit's cells for nutrients, thus reducing the amount of microbial metabolites that inhibit the growth of the animal $[8,12]$. Use of this group of drugs often results in side effects, so there is a need to find alternative means to stimulate the growth of animals. These drugs primarily include forage probiotics, contributing to the increase of resistance of the animal

* Corresponding author: alena.kurchaeva@yandex.ru 
body, normalization of intestinal microbiocenosis, improving the processes of assimilation of feed nutrients [9]. Recently, to solve this problem, the use of probiotic feed additives was suggested. They are involved in creating conditions for forecasting and managing the quality of products by in vivo biocorrection of nutritional status, which affects the quality of products obtained from raw meat raw materials.

Rabbit meat is considered a dietary raw meat, it is characterized by a pale pink color, rather delicate consistency and is characterized by thin-fibrous muscle tissue. Connective tissue in rabbit meat is insignificant, so it is characterized by a delicate consistency. Meat rabbit contains many nitrogenous, mineral (acidic salts of phosphorus (246 $\mathrm{mg} \%$ ) and potassium (364 mg \%)). The presence of extractives gives the meat a specific smell and taste. The cholesterol content in rabbit meat is $25 \mathrm{mg}$ per $100 \mathrm{~g}$ of meat $[9,12]$.

At balanced feeding, the body of rabbits accumulates a large number of biologically active substances from grain raw materials. They are: polyunsaturated fatty acids, dietary fibers, vitamins, minerals, as well as minerals and vitamins necessary for humans: iron, selenium, fluorine, cobalt, b vitamins, vitamin $\mathrm{C}$, which predetermines the use of this type of meat in therapeutic and preventive nutrition.

When creating full-fledged diets, it is promising to use safe mineral feed additives that contribute to the enrichment of the body with easily accessible forms of macro-and microelements that take an active part in metabolism. In addition, the use of mineral additives helps to increase the productivity of rabbits and improve the quality of products, is one of the factors to strengthen the feed base, reducing the consumption of feed per unit of production.

The aim of the work is to increase the meat productivity of rabbits on the basis of complex use of "Pro-Stor" synbiotic preparation and evaluation of its impact on the quality of the obtained meat raw materials.

\section{Materials and methods}

Industrial approbation was carried out by the method of balanced group-analogues according to generally accepted methods at the premises of the industrial complex of LLC "Lipetsk rabbit" in 2018-2019. Experimental groups were formed from clinically healthy animals.

For the experiment, 200 rabbits of the hybrid form "Hypharm" of French breeding were selected at the age of 45 days, divided into 2 groups. For each group, 100 animals were selected. The maintenance and feeding of rabbits corresponded to zoo-hygienic and zootechnical norms. We used dry type of feeding - granular all-mash. Animals had unlimited access to water, drinking with nipple drinkers. Experimental and control groups of animals were in the same conditions of maintenance, feeding and care. As the main diet we used feed PZK-90, obtained on the basis of cereals, sunflower oil cake, wheat bran, herbal flour and premix KVP P90-1K.
Experiments, previously conducted in 2016-2017, established a positive effect of "Pro-Stor" synbiotic supplements on the productivity of rabbits. During the industrial testing, the formed control group of rabbits received a basic diet consisting of PZK-90 feed, the rabbits of the experimental group received PZK feed-92$60-18$, to which was introduced "Pro-Stor" synbiotic in the amount of $1 \mathrm{~g} / \mathrm{kg}$ of all-mash, respectively.

Pro-Stor is a new-generation synbiotic feed additive; it contains cultures of microorganisms Bacillus subtillis, Bacillus licheniformis immobilized on a phytosorbent, lactic acid bacteria and products of their metabolism-a set of the most important enzymes, biologically active substances, vitamins and amino acids. It stimulates the digestion of fiber, proteins, polysaccharides, neutralizes toxins, suppresses pathogenic microflora, providing improved metabolism, motor and secretory function of the digestive system, improves feed conversion, withstands high temperature production of granular feed. "Pro-Stor" contains lactic acid microorganisms at least in the amount of $5 \cdot 10^{6} \mathrm{CFU} / \mathrm{g}$, and at least $2 \cdot 10^{7} \mathrm{CFU} / \mathrm{g}$ of Bacillus subtillis.

Dynamics of live weight was taken into account by individual weighing. To determine the meat productivity, 3 rabbits from each group were slaughtered according to the VIZ method, the meat quality was assessed according to the methods $[13,14]$.

The quality of rabbit meat was evaluated according to GOST 20235.0-74. Assessment of the chemical composition and biological value, physical and chemical parameters of rabbit meat was carried out in accordance with the recommendations [15].

\section{Results and discussion}

In recent years, instead of antibiotics, probiotic complexes of different species composition are widely used at growing young rabbits, including those containing active components that have a direct impact on the processes of homeostasis. In addition, the probiotic drugs, unlike antibiotics, do not have a detrimental effect on the intestinal microflora, but displace the pathogenic microflora, which had been causing various diseases of the gastrointestinal tract.

When growing young rabbits, the intensity of the build-up of live weight is important, which reflects the nature and level of feeding of young rabbits. At the stage of the experiment, the weight of rabbits of the control and experimental groups was almost the same and averaged $65.0 \mathrm{~g}$. upon reaching the age of 105 days, rabbits of the 1st group (control) were characterized by a live mass that was less than the mass of rabbits of the 2nd group-by $219.0 \mathrm{~g}$, or $6.76 \%(\mathrm{P}<0.01)$ (table 1$)$.

The main indicator characterizing meat quality of rabbits is their pre-slaughter weight, chilled carcass weight, carcass yield, and the ratio of muscle and bone tissue, defined as an index of meatiness [16-20].

The positive effect of the synbiotic drug used has been confirmed by morphological and biochemical parameters of the blood of experimental rabbits (table 2). 
Table 1. Growth Rate of live weight of rabbits, $g$

\begin{tabular}{|c|c|c|}
\hline \multirow{2}{*}{$\begin{array}{c}\text { Age, } \\
\text { days' }\end{array}$} & \multicolumn{2}{|c|}{ Group } \\
\cline { 2 - 3 } & $\begin{array}{c}\text { Group 1 } \\
\text { (control) }\end{array}$ & $\begin{array}{c}\text { Group 2 } \\
\text { (experimental) }\end{array}$ \\
\hline 1 & $64.95 \pm 1.53$ & $65.80 \pm 0.87$ \\
\hline 45 & $1527.0 \pm 25.05$ & $1537.0 \pm 13.73$ \\
\hline 105 & $3240.0 \pm 8.54$ & $3459.0 \pm 16.58$ \\
\hline Average daily growth & $28.68 \pm 2.37$ & $32.20 \pm 3.96$ \\
\hline
\end{tabular}

Table 2. Morphological and biochemical parameters of rabbit blood

\begin{tabular}{|c|c|c|}
\hline \multirow{2}{*}{$\begin{array}{l}\text { Age, } \\
\text { days' }\end{array}$} & \multicolumn{2}{|c|}{ Group } \\
\hline & $\begin{array}{l}\text { Group 1 } \\
\text { (control) }\end{array}$ & $\begin{array}{c}\text { Group } 2 \\
\text { (experimental) }\end{array}$ \\
\hline \multicolumn{3}{|c|}{ At the beginning of fattening ( 45 days) } \\
\hline Total protein, $\mathrm{g} / 1$ & $70.22 \pm 0.24$ & $70.34 \pm 0.27$ \\
\hline Globulins, g/ 1 & $33.99 \pm 0.06$ & $34.04 \pm 0.11$ \\
\hline Albumins, g/ 1 & $36.23 \pm 0.17$ & $36.30 \pm 0.27$ \\
\hline $\mathrm{A} / \mathrm{G}$ & 1.06 & 1.06 \\
\hline Red blood cells, $10^{12} / 1$ & $4.75 \pm 0.07$ & $4,69 \pm 0,04$ \\
\hline Leukocytes, $10^{9} / 1$ & $6.98 \pm 0.11$ & $6.96 \pm 0.19$ \\
\hline Hemoglobin, g/ 1 & $109.75 \pm 0.21$ & $111.27 \pm 1.28$ \\
\hline \multicolumn{3}{|c|}{ At the end of fattening (105 days) } \\
\hline Total protein, $\mathrm{g} / 1$ & $70.29 \pm 0.11$ & $73.90 \pm 1.74$ \\
\hline Globulins, g/ 1 & $34.08 \pm 0.12$ & $34.66 \pm 0.42$ \\
\hline Albumins, $\mathrm{g} / \mathrm{l}$ & $36.21 \pm 0.16$ & $39.24 \pm 1.31$ \\
\hline $\mathrm{A} / \mathrm{G}$ & 1.06 & 1.13 \\
\hline Red blood cells, $10^{12} / 1$ & $5.48 \pm 0.16$ & $6.29 \pm 0.21$ \\
\hline Leukocytes, $10^{9} / 1$ & $6.41 \pm 0.10$ & $6.29 \pm 0.11$ \\
\hline Hemoglobin, $\mathrm{g} / \mathrm{l}$ & $110.12 \pm 0.07$ & $117.40 \pm 3.92$ \\
\hline
\end{tabular}

The data obtained show that the protein content is higher in the blood of rabbits of the experimental group by $3.61 \mathrm{~g} / \mathrm{l}$ or $5.06 \%$. A similar trend is observed in the content of albumins and globulins.

The highest pre-slaughter weight was in the 2nd (experimental) group of rabbits and amounted to $3226 \mathrm{~g}$, which exceeded the pre-slaughter weight compared to the 1 st group (control) by $161.0 \mathrm{~g}$ or $5.25 \%$ (table 3 ). In the 2nd (experimental) group of rabbits, the slaughter yield of the carcass was $59.89 \%$, which is more than in the 1 st (control) group by $5.67 \%$.

Rabbits of the $2^{\text {nd }}$ group exceeded animals of the $1^{\text {st }}$ group (control) by weight of the chilled carcass on $276,0 \mathrm{~g}(16,67 \%$; $\mathrm{P}<0,05)$. A similar regularity was observed in the mass of muscle tissue obtained after boning. The calculated index of meat content showed that rabbits receiving all-mash PZK-90-2 with the introduction of "ProStor" probiotic additive at a dosage of $1.0 \mathrm{~g}$ per $\mathrm{kg}$ of feed (experimental group) have a higher index of metiness - 4.35, compared with rabbits of the control group -3.35 units, respectively.

For qualitative characteristics of rabbit meat, their anatomical cutting was carried out, which confirmed the obvious intergroup differences in the morphological composition of rabbit carcasses and the yield of muscle tissue. It was found that the highest yield of muscle tissue was recorded in rabbit carcasses, which were fed with "ProStor".

The yield of muscle tissue of rabbits of the experimental group exceeded this indicator of rabbits of the control group by $23.84 \%$
Table 3. Morphological composition of carcasses ( $n=9)$

\begin{tabular}{|l|c|c|}
\hline \multicolumn{1}{|c|}{ Indicator } & $\begin{array}{c}\text { Group 1 } \\
\text { (control) }\end{array}$ & $\begin{array}{c}\text { Group 2 } \\
\text { (experimental) }\end{array}$ \\
\hline Pre-slaughter live weight, g & $3065.0 \pm 16.51$ & $3226.0 \pm 11.35$ \\
\hline Weight of cooled carcass, g & $1656.0 \pm 10.75$ & $1932.0 \pm 18.26$ \\
\hline Slaughter output, \% & $54.02 \pm 1.37$ & $59.89 \pm 0.44$ \\
\hline Meat index & $3,35 \pm 0,78$ & $4.35 \pm 0.55$ \\
\hline
\end{tabular}

High biological plasticity and adaptability to a variety of conditions distinguishes rabbits from all farm animals. It should be noted that insufficient and unbalanced feeding leads to a delay in the growth of individual parts of the animal body, especially decreases the output of muscle tissue and increases the proportion of bone and connective tissues. Therefore, the results of the study of the morphological composition of rabbit carcasses allow us more accurately to characterize the changes that occur against the background of the use of "ProStor".

It is known that the chemical composition of meat largely determines its nutritional and biological value, which is determined by a set of necessary food nutrients [21-26].

Table 4 shows the chemical composition of the average rabbit meat sample.

The use of "Pro-Stor" synbiotic in feeding the rabbits contributed to an increase in the mass fraction of protein in muscle tissue. The highest protein content was observed in the meat of rabbits of the 2nd (experimental) group and amounted to $23.37 \%$. The maximum amount of mineral substances was observed in rabbits of the $2^{\text {nd }}$ (experimental) group, which amounted to 1.18 per cent.

Table 4. Chemical composition of the average sample of rabbit meat, $\mathrm{M} \pm \mathrm{s}$

\begin{tabular}{|l|c|c|}
\hline \multirow{2}{*}{ Indicator } & \multicolumn{2}{|c|}{ Group } \\
\cline { 2 - 3 } & $\begin{array}{c}\text { Group 1 } \\
\text { (control) }\end{array}$ & $\begin{array}{c}\text { Group 2 } \\
\text { (experimental) }\end{array}$ \\
\hline Mass fraction of moisture, \% & 72.31 & 71.49 \\
\hline Mass fraction of protein, \% & 21.36 & 23.37 \\
\hline Mass fraction of fat, \% & 5.21 & 3.96 \\
\hline Mass fraction of ash, \% & 1.12 & 1.18 \\
\hline
\end{tabular}

Rabbit meat is characterized by the ability to meet the daily needs of the body in basic nutrients and is a promising raw material for food rations, including for functional foods, which is confirmed by the presence of macro- and microelements in the composition (table 5).

The results obtained are consistent with the data obtained earlier by a number of researchers (Antipova L.V., Popova Ya. A., 2018).

The organoleptic evaluation of meat and broth of rabbits of the control and experimental groups showed a positive effect of probiotic feed additive "Pro-Stor" on the formation of taste and aroma profile of cooked meat (table 6).

The highest score was shown by samples of cooked meat obtained from the carcasses of the experimental group. Samples of cooked meat obtained from the carcasses of rabbits of the control and first groups had lower scores. 
Table 5. Mineral composition of the medium sample of rabbit meat

\begin{tabular}{|l|c|c|}
\hline \multirow{2}{*}{ Indicator } & \multicolumn{2}{|c|}{ Group } \\
\cline { 2 - 3 } & $\begin{array}{c}\text { Group 1 } \\
\text { (control) }\end{array}$ & $\begin{array}{c}\text { Group 2 } \\
\text { (experimental) }\end{array}$ \\
\hline \multicolumn{3}{|c|}{ Macronutrients, mg } \\
\hline Sodium & 60.5 & 62.4 \\
\hline Magnesium & 23.7 & 24.2 \\
\hline Calcium & 22.0 & 24.2 \\
\hline Potassium & 348.0 & 356.0 \\
\hline Phosphorus & 210.0 & 213.4 \\
\hline \multicolumn{3}{|c|}{ Trace elements, mg } \\
\hline Copper & 0.13 & 0.10 \\
\hline Iodine & 0.00104 & 0.00101 \\
\hline Fluorine & 0.068 & 0.055 \\
\hline
\end{tabular}

Table 6. Tasting evaluation of rabbit meat of control and experimental groups

\begin{tabular}{|l|c|c|}
\hline \multirow{2}{*}{ Indicator } & \multicolumn{2}{|c|}{ Group } \\
\cline { 2 - 3 } & $\begin{array}{c}\text { Group 1 } \\
\text { (control) }\end{array}$ & $\begin{array}{c}\text { Group 2 } \\
\text { (experimental) }\end{array}$ \\
\hline Appearance & 7.20 & 7.50 \\
\hline Aroma & 7.15 & 7.60 \\
\hline Consistency & 7.50 & 8.00 \\
\hline Taste & 7.00 & 8.00 \\
\hline Juiciness & 7.20 & 7.80 \\
\hline
\end{tabular}

Table 7. The amino acid profile of the average sample of muscle tissue

\begin{tabular}{|c|c|c|}
\hline \multirow[t]{2}{*}{ Amino acid } & \multicolumn{2}{|c|}{ Group } \\
\hline & $\begin{array}{l}\text { Group 1 } \\
\text { (control) }\end{array}$ & $\begin{array}{c}\text { Group } 2 \\
\text { (experimental) }\end{array}$ \\
\hline \multicolumn{3}{|c|}{ Essential amino acids, g / 100 g product } \\
\hline Valine & 0.918 & 0.976 \\
\hline Isoleucine & 0.822 & 0.910 \\
\hline Leucine & 1.386 & 1.652 \\
\hline Lysine & 1.556 & 1.710 \\
\hline $\begin{array}{l}\text { Methionine+ } \\
\text { cystine }\end{array}$ & 0.841 & 0.910 \\
\hline Threonine & 0.785 & 0.856 \\
\hline Tryptophan & 0.192 & 0.234 \\
\hline $\begin{array}{l}\text { Phenylalanine+ } \\
\text { tyrosine }\end{array}$ & 1.686 & 1.791 \\
\hline Histidine & 0.341 & 0.421 \\
\hline \multicolumn{3}{|c|}{ Interchangeable amino acids, g / $100 \mathrm{~g}$ product } \\
\hline Alanine & 1.064 & 1.095 \\
\hline Arginine & 1.610 & 1.657 \\
\hline Aspartic acid & 1.520 & 1.531 \\
\hline Glycine & 0.894 & 0.910 \\
\hline Glutamic acid & 2.712 & 2.746 \\
\hline Oxyproline & 0.066 & 0.070 \\
\hline Proline & 0.578 & 0.576 \\
\hline Serine & 0.629 & 0.624 \\
\hline
\end{tabular}

The amino acid composition of the average rabbit meat sample was studied (table 7).

According to the results of the study of the amino acid composition of the average sample of muscle tissue of rabbits, the presence of all essential amino acids was established. Meat of rabbits grown with the use of synbiotic preparation "Pro-Stor" (table 8) contains valine, isoleucine, leucine, lysine, methionine+cystine, threonine, tryptophan and phenylalanine in significant quantities, which indicates the protein value of meat of rabbits of experimental groups

Evaluation of functional and technological properties of rabbit meat (MBA (moisture-binding capacity), MHA (moisture-holding ability), FHC (fat- holding), ES (emulsifying capacity) and SE (emulsion stability)) also revealed a clear positive dynamics (table 8 ).

Table 8. Functional and technological parameters of rabbit meat

\begin{tabular}{|l|c|c|}
\hline \multicolumn{1}{|c|}{ Indicator } & $\begin{array}{c}\text { Group 1 } \\
\text { (control) }\end{array}$ & $\begin{array}{c}\text { Group 2 } \\
\text { (experimental } \\
\text { group) }\end{array}$ \\
\hline $\begin{array}{l}\text { Moisture binding capacity, \% } \\
\text { (MBC) }\end{array}$ & $61.25 \pm 0.11$ & $64.19 \pm 0.54$ \\
\hline $\begin{array}{l}\text { Water-holding capacity, \% } \\
\text { (WHC) }\end{array}$ & $54.20 \pm 0.36$ & $61.64 \pm 0.62$ \\
\hline $\begin{array}{l}\text { Fat Holding capacity ability, } \\
\% \text { (SA) }\end{array}$ & $61.90 \pm 1.31$ & $63.17 \pm 1.22$ \\
\hline Emulsifying ability, \% (EP) & $29.27 \pm 0.90$ & $33.41 \pm 0.55$ \\
\hline Emulsion stability, \% (ES) & $48.47 \pm 0.41$ & $53.40 \pm 0.42$ \\
\hline
\end{tabular}

WHC was at a high level and exceeded the control group by 3.69 and $9.98 \%$, respectively, which can be explained by the higher protein content and lower fat content in the meat of the experimental group of rabbits.

The most important indicators in terms of assessing the technological potential of rabbit meat is $\mathrm{MBC}$ and FHC, which characterize the ability of myofibrill proteins to form a protein-fat matrix. These indicators are variable and depend on the type of feeding and fatness of the rabbit. The study has found that MBC (5.48 and $9.67 \%)$ and FHC (1.34 and $8.25 \%)$ of the experimental groups are superior to similar indicators of the control group of rabbits.

Thus, the use of additives with probiotic properties in the feed rations of rabbits has a positive impact on the biological and nutritional value of the obtained meat resources of the rabbit industry.

\section{Conclusion}

The study has shown that the use of synbiotic drug "ProStor" in a dosage of $1.0 \mathrm{~g} / \mathrm{kg}$ of feed contributes to the growth rate of fattened young rabbits, has a positive effect on the physiological status, morphological composition of rabbit carcasses, as well as technological properties, nutritional value of rabbit meat.

\section{References}

1. V.N. Alexandrov, K.V. Kharlamov, A.R. Zhvakina, T.L. Chichkova, Productivity of purebred and crossbred young rabbits of domestic breeds white giant and soviet chinchilla, Rabbit and animal husbandry, 6, 16-18 (2013)

2. E.V. Pechenkin, A.A. Sagirov, O.V. Gorelik, Meat productivity of rabbits of different breeds, Proc. of Orenburg state agrar. Univer., 1(45), 127-129 (2014) 
3. Yu.A. Kalugin, N.A. Balakirev, O.I. Fedorova, Meat productivity of rabbits, Veter., animal sci. and biotechnol., 10, 38-43 (2015)

4. A.V. Vostroilov, E.E. Kurchaeva, The Use of probiotic preparation "Board 3.0" in the diet of rabbits, in Coll. of articles IX Int. sci.-pract. Conf. "Breakthrough research: problems, patterns, prospects" (in 4 parts), 156-159 (2017)

5. A.M. Puchnin, A.A. Fomin, V.V. Smiryagin, Probiotic supplements "Bacell" to feed in growing rabbits, Bull. of Tambov Univer., Ser. Natural and techn. Sci., 17(1), 399-401 (2012)

6. A.M. Puchnin, A.A. Fomin, V.V. Smiryagin, The use of probiotic preparation "BACELL" on the productivity of young rabbits, Bull. of the Tambov Univer., Ser. Natural and techn. Sci., 16(2), 678-680 (2011)

7. L.G. Gorkovenko, N.Ah. Yurina, N.Ah. Omelchenko, N.N. Omelchenko, The effectiveness of the use of probiotic additives to feed "Bacell-m" in the diet of rabbits, Veter. Kuban., 1, 19-21 (2016)

8. E.N. Chernenkov, I.V. Mironov, The quality of rabbit meat when fed probiotic "Bogometer", Bull. of Altai state agrar. Univer., 10(132), 104-108 (2015)

9. E.N. Chernenkov, A.Ya. Gizatov, Dynamics of changes in meat productivity of rabbits when used in the diet of probiotic additives Biohumer, Proc. of the Samara state agricult. Acad. 1, 128-131 (2014)

10. A.V. Vorobyov, Veterinary and sanitary indicators of rabbit meat under the influence of experimental biological products, Russ. J. Of veter. Sanitat., hygiene and ecology, 1, 210-215 (2012)

11. A. Pavelková, J. Tkáčová, K. Červienková, O. Bučko, The rabbit meat quality after different feeding, Potravinarstvo, 11(1), 634-640 (2017)

12. E.N. Chernenkov, I.V. Mironov, A.Y. Gizatov, Influence of feeding of the drug Biohemical on carcass quality and morphological composition of carcasses of rabbits, News of the Orenb. state agrar. Univer., 4(48), 146-148 (2014)

13. A.V. Vostroilov, E.E. Kurchaeva, V.L. Pashchenko, E.V. Mikhailov, Influence of probiotic VetKor on the meat productivity and morphological characteristics of the stomach and liver of rabbits, in The Mat. of XVII Int. sci. res. competition "The Best Gaucha article 2018, ”29-34 (Penza, 2018)

14. I.F. Gorlov, V.A. Barannikov, N.Ah. Yurina, N.Ah. Omelchenko, E.A. Maxim, The productive effect of the complex probiotic supplements, Agricult. Res. magazine, 11, 17-20 (2014)

15. L.V. Antipova, I.A. Glotova, I.A. Rogov, Methods of research of meat and meat products (Kolos, Moscow, 2001)

16. G. Capra, R. Martínez, F. Fradiletti et al., Meat quality of rabbits reared with two different feeding strategies: with or without fresh alfalfa ad libitum, World Rabbit Sci., 21(13), 23-32 (2013)

17. A.P. Efremov, P.N. Martynov, Interior differences of rabbits of different ages, Fundam. Res., 5, 138-141 (2012)

18. M. Palazzo, F. Vizzarri, M. Nardoia et al., Dietary lippia citriodora extract in rabbit feeding: effects on quality of carcass and meat, Archiv fur Tierzucht, 58(2), 355-364 (2015)

19. N.V. Berestov, L.Ya. Makarenko, Comparative assessment of the conditions for growing rabbits of the silver breed according to productive and biological indicators, Bulletin of Krasnoyarsk State Agrarian University, 3, 129-134 (2016)

20. V.I. Kolmatsky, Prospects of industrial production of rabbit meat in Russia, Rabbit Breed. and animal husbandry, 4, 30-33 (2012)

21. H. Giang, T. Viet, J. Lindberg, Growth performance, digestibility, gut environment and health status in weaned piglets fed a diet supplied with a complex of lactic acid bacteria alone or in combination with Bacillus subtilis and Saccharomyces boulardii, Living Sci., 143, 32-41 (2012)

22. Protein and amino acid requirements in human nutrition: report of a Joint FAO/WHO/UNU Expert Consultation WHO technical report series, 935, 256 (WHO, Geneva, 2007)

23. A.I. Shevchenko, S.A. Shevchenko, Yu.N. Fedorov, Natural resistance of poultry and its pharmacocorrection by probiotics and synbiotics, Agricult. Boil., 2, 93-98 (2013)

24. K.V. Kharlamov, N.A. Minaev, A.R. Zhvakina, Comparative characteristic of amino acid composition of meat of purebred and crossbred young rabbits, Russ. Agricult. Sci., 4, 68-71 (2016)

25. Z. Dalle, Zs. Szendrö, The role of rabbit meat as functional food, Meat Sci., 88(3), 319-331 (2011)

26. P. Bielanski, J. Zajac, J. Fiji, Effect of genetic variation of growth rate and meat quality in rabbits, In Proc. of the 7th World Rabbit Congress, 561-566 (World Rabbit Science Association, Valencia, Spain, 2000) 